\title{
What Happens in the Language Classroom in regards to Communication? An analysis of the Cooperative Principle $^{1}$
}

\author{
¿Qué ocurre en el aula de idiomas con relación a la \\ comunicación? Análisis del principio de cooperación
}

\author{
Willian Alexander Mora Menjura ${ }^{2}$ \\ Universidad de Boyacá - Tunja \\ willianjeronimora@gmail.com
}

Received: March 1, 2017

Accepted: June 3, 2017

How to cite this article (APA, 6th ed.): Mora-Menjura, W. (2017). What Happens in the Language Classroom in regards to Communication? An analysis of the Cooperative Principle. Enletawa Journal, 10 (2), 63 - 78

\begin{abstract}
The concept of communication in the field of education has been discussed by language teachers, scholars, and researchers among others. This article analyzes and reflects on the way in which language teachers and students communicate in the language classroom. This analysis was done based on the rules of the Cooperative Principle, proposed by Paul Grice in 1975. The inquiry consisted on studying how the teacher and students flout the maxims of communication proposed by the principle (quality, quantity, relation and manner). For the analysis, an eighth grade English class

1 Reflective article

2 Willian Alexander Mora Menjura holds a bachelor's degree in Modern Languages Teaching from Universidad Pedagógica y Tecnológica de Colombia (UPTC). He is also an M.A. candidate of the Master's Program in Language Teaching at the same university. He has been teaching English and Spanish for the past 3 years in different private and public schools. Currently, he is a full-time professor at Universidad de Boyacá.
\end{abstract}


at a private school was recorded, and parts of the video were extracted. This analysis is not focused on studying how teachers and students make mistakes, but rather how communication is carried out in the language classroom.

Key words: Communication, language classroom, Grice's cooperative principle, maxims of communication, flout of maxims.

\section{Resumen}

El concepto de comunicación en el campo de la educación ha sido discutido por profesores de idiomas, académicos, investigadores, entre otros. Este artículo analiza y reflexiona sobre la forma en que un profesor de idiomas y los estudiantes se comunican en el aula de idiomas. Este análisis se realiza con base en las reglas del Principio Cooperativo, propuesto por Paul Grice en 1975. El análisis consiste en estudiar cómo el docente y los estudiantes incumplen las máximas propuestas en este principio (calidad, cantidad, relación y manera). Para el análisis, se extrajeron algunas partes de un video de clase de inglés, grabado en una escuela privada. Los estudiantes están en octavo grado. El análisis no se centra en estudiar cómo los maestros y los estudiantes cometen errores, sino en analizar cómo se lleva a cabo la comunicación en el aula de idiomas.

Palabras clave: Comunicación, aula de idiomas, principios de cooperación de Grice, máximas de comunicación, incumplimiento de máximas. 


\section{Introduction}

Nowadays, English Language Teaching has focused not only on teaching grammar structures and basic vocabulary or common phrases, but it has also taken into account the communicative aspect. That is one of the reasons why recent language teaching methods, such as the communicative language teaching, have started focusing on oral communication rather than grammatical aspects. In Colombia, the language classroom is generally the place where English learners have the opportunity to be in contact with the language. According to Fajardo (2013), the language classroom is the place where interaction happens, which is important for foreign language learning.

Speakers need to communicate in order to transfer their ideas, express their feelings, and solve different issues. Normally, people can communicate with others in their mother tongue, but speakers may find barriers and difficulty expressing their ideas or problems when they want to speak in a foreign language. As mentioned by Helfrich and Bosh (as cited in Kocaman, 2016) "In order to manage these situations they need to have a good command of communication skill and they should use communication strategies in an effective and successful way" (p. 1780). In most cases, the language teacher is the only person who fulfills these requirements when speaking English in the classroom.

Teachers try to communicate with their students in the foreign language, but sometimes communication is inter- rupted due to the lack of vocabulary, misunderstandings of false cognates, and other difficulties attributed to the student. In the end, communication becomes mostly unilateral, directed by the teacher. Harzing and Feely (as cited in Kocaman, 2016), point out that "language barriers are expectable risks such as lack of word knowledge, grammar, and mispronunciation and so on. Lack of word knowledge affects all skills. It is due to the insufficient vocabulary that learners cannot be productive enough in speaking" (p. 1782)

According to Grice (1975), communication, seen as a communicative act, needs the cooperation of its participants. When I, as a speaker, ask a question, I intend to cooperate with the person to whom the question was asked. That is to say, I do not expect or hope that the other speaker will not answer or provide the wrong answer. Instead, I hope that s/he can answer my question and solve my problem.

Talking about cooperation in conversation analysis has been a field of research and study for many scholars. There have been some problems in regards to the meaning of the concept. According to Davies (2000), cooperation is a term that is used mainly in linguistic literature to characterize human behavior in talk. Grice (1975) refers to this concept as the relation between the meaning of a statement and any implicit meaning this sentence may have. However, Davies (2000) states that Grice does not mention whether interaction is cooperative. By definition, "cooperative" usually refers to 
a situation in which people work together to do something, and Grice focuses more on the meaning of the message rather than on the human act.

The purpose of this article is to reflect upon the process of communication that is carried out in the classroom between teachers and students. This can guide educators to understand how communication can be enhanced in the language classroom. Some scholars and teachers may think that communication happens in the classroom, even if students do not understand what their English teachers say. Some others may think that if one of the speakers does not understand what the other speaker communicates, communication does not occur. In my opinion, communication is a process where both the transmitter and the receiver understand or have an idea of what is being said in the conversation. In this sense, it is important to analyze Grice's concept about saying and meaning.

...what a speaker says and what a speaker means are interrelated: there is a sense of 'saying' on which you can't say anything without meaning something; and if you didn't mean anything, it's hard to see how you can be regarded as having said something. (Grice, 1975, as cited in Wharton, 2003, p. 208)

Most of the studies done about cooperative principles have focused on conversations in which two people interact. Also, these principles have been studied in written messages, advertisements, and texts. This reflective study is based on Grice's cooperative principle, in which the author researches on the maxims proposed by this principle. In this study, the language classroom was the context analyzed.

Paul Grice based his cooperative principles on four categories that he called maxims. These are: maxim of quality, maxim of quantity, maxim of relation or relevance, and maxim of manner. Each one of these maxims will be defined in the next section. To study what happens in the language classroom in terms of communication, the author analyzes the way in which these maxims are flouted. In other words, the study is done on how speakers infringe these maxims and do not follow the patterns stated by each one.

The analysis does not intend to focus on the mistakes that students and teachers make in the English language classroom. Instead, it intends to study and analyze how the process of communication unfolds in the classroom. Perhaps, this may contribute to further research studies about reflective teaching, conversation analysis, and many other areas of study.

For the past decades, the communicative approach has been used by many teachers in the classroom English teachers have focused on following the communicative approach. Yet, how effective is this method in a monolingual context where English is a subject taken in educative institutions for only a few hours? Given this inquiry, the context for this study was an English classroom in which the communicative approach is implemented.

\section{Theoretical background}

\section{Cooperative principle}

Cooperation is a term often used in 
linguistic literature meant to characterize human behavior in conversation (Nelson and Foulkes, 2000). Grice (1975) states that participants in a conversation obey a general 'Cooperative Principle', which is expected to be in force whenever a conversation unfolds. "Make your contribution such as required, at the stage at which it occurs, by the accepted purpose or direction of the talk exchange in which you are engaged" (Grice, 1975, p. 45). According to Fais (as cited in Davis, 2000), "one of the defining features of conversation is that it is cooperative in nature" (p. 4).

As mentioned before, this study seeks to analyze the Cooperative Principle proposed by Grice (1975) which contains the following four maxims: maxim of quantity, maxim of quality, maxim of relevance or relation, and maxim of manner.

\section{Maxims of cooperation}

Maxim of quantity. Grice (1975) suggests that people must make their contribution as informative as is required (for the purpose of exchange). In other words, people should not give more information than necessary. Generally, when this maxim is flouted or violated, the person who is giving the information tends to give more details than he or she was asked to answer. In the Colombian, this kind of violation is uncommon to find in the English language classroom, since most of the students do not speak the foreign language to the extent that more details would be given. Thus, students tend to give only the details asked for.
Maxim of quality. According to Grice (1975), speakers must not say what they believe to be false. They must not say that for which they lack adequate evidence. The Maxim of Quality requires that the information provided in conversations be genuine and justified. Grice suggests this maxim in order to explain a certain kind of regularity in conversational behavior with respect to the authenticity of information provided during each turn in the conversation.

Speakers may flout this maxim when they do not give or provide real or adequate information when answering questions.

Maxim of relation or relevance. This maxim explains a certain kind of regularity in conversational behavior in relation to the relevance of information provided when people answer questions. It also has to do with how the answer relates to the question the speaker asks (Grice, 1975).

Students may flout this maxim when they do not answer what the teachers asks or when students do not give a relevant answer. This maxim may be flouted by students if teachers feel unsatisfied with the answer.

Maxim of manner. Grice (1975) states that this maxim has to do with avoiding obscurity of expression, as well as ambiguity. Grice states that talking must be brief (avoiding unnecessary prolixity) and orderly. This maxim is also related to how people say what they say in the conversation. Grice proposes this 
maxim in order to explain a certain kind of regularity in conversational behavior with respect to the way information is provided when each speaker talks. Speakers may flout this maxim when they do not pay attention to the order of presenting information, vagueness and ambiguity, selection of words, attitude, and even facial and gestural expressions.

\section{Communication}

The Merriam-Webster Dictionary Online (n.d.) defines communication as "an act or instance of transmitting". The Cambridge Dictionary Online (n.d.) indicates that the word communication comes from Latin word communis, which means to convey, and the adjective communicable, which means transmissible. Partridge integrates different concepts and states "in the light of this information, it can be stated that the word communication involves the meanings of transmission, channel and mutuality" (As cited in Kocaman, 2016, p. 1780).

\section{Theory of communication}

Grice's theory of communication consists of two parts. According to Neale (as cited in Shardimgaliev, 2016), one of these parts is Grice's theory of meaning, and the other is Grice's theory of communication. The first theory focuses on explaining how certain objects are said to have meaning at all. Grice proposes two categories to distinguish meaning: natural and nonnatural meaning. The first concept relates to the meaning that the word or sentence has by itself. What this means is that most people will imagine a car when they hear the word "car". For the case of nonnatural meaning, Grice gives an example of a bell being rung three times, which means that the bus is full. However, the rings do not have the natural meaning of the word "full". The meaning was either conventionally proposed, or travelers may infer that those rings mean full.

\section{Saying and meaning}

Based on Grice's theory of meaning, it is important to understand the way in which we interact with others. What is it that I want to say and what is it that I want to mean. In this case, we find two different concepts: saying and meaning. These two concepts are connected to "say" and "what is said". For Grice, say has to do with the utterance that the speaker uses to communicate. The speaker says something, but in many cases, what is said by the speaker does not necessarily correspond to what the speaker wants to express. In the second case, "Grice uses the phrase what is said as a technical term for the truth conditional content of an expression, which may in fact be somewhat less than the full conventional content" (Levinson, as cited in Wharton, 2003, p.211). Also, what is said (in Grice's special sense) "is what speakers mean mostly through the conventional content of the sentences they utter-indeed, through only that part that affects the truth of their utterances" (Clark, as cited in Wharton, 2003, p. 211).

\section{Violation of maxims}

According to Davis (1997), Grice states that there is a recognized way of speaking 
which we all accept as standard behavior. When speakers produce, or hear, an utterance, they generally assume that it will be honest, will have the right amount of information, or will be relevant. If the utterance breaks this model, people do not assume that the utterance is nonsense. Rather, they assume that an appropriate meaning is to be inferred. In Grice's words, a maxim has been flouted, and an implicature generated (p.2).

When we converse, it is not common to focus on how the other person answers the questions we ask. Sometimes, they answer them directly. In other cases, they answer them with different ideas, or they just do not answer at all. Instead, they change the topic of the conversation. According to Escavy (1998), maxims of the cooperative principle are frequently infringed, but these infractions are also used as a cooperative resource through conversational implicatures. The violation of a maxim supposes implied information, adjusted to the cooperation principle. There are, on the contrary, violations that are not cooperative and that, therefore, contradict the goodness of the cooperative principle. Other violations are produced due to the poor technical elaboration of the messages. This is called "antagonistic" because these messages do not respect the space of the interlocutor or the cooperative principle. Although these messages are produced especially in written communication, they can be transferred to cases of oral communication $^{3}$.

3 Translated by the author for publication purposes.

\section{Methodology}

This article utilizes 11 extracts of a class video recorded for research and pedagogical purposes. Each extract is analyzed in order to identify and recognize how communication is carried out by teachers and students in the classroom. Once the class was video-recorded, the researcher started transcribing it. Once the video was transcribed, the researcher studied the possible fragments where maxims were violated.

For the explanation of this phenomenon, the author first shows which maxim will be analyzed. Then, some extracts are provided in order to demonstrate how the maxim was violated. Finally, the author explains and reflects about this issue.

\section{Extracts where maxims are flouted \\ Maxim of quality}

"Speakers must not say what they believe to be false. They must not say that for which they lack adequate evidence" (Grice, 1975).

\section{Extract 1:}

S: How do you say cazar?

(to hunt)

T: Houses? Aaaa cazar? Hunt

In the previous example, the teacher realizes the mistake she made. However, according to Grice's theory, the teacher provided a wrong answer. This aspect breaks the authenticity of the answer; therefore, the information provided to the student's answer is not appropriate. 
When we, as teachers, provide wrong information, this may cause misunderstandings in our students' learning process. Giving correct and appropriate information not only makes the person asking the question feel satisfied, but it also allows an effective process of communication. In the English language classroom, students tend to believe what their teachers tell them. This may happen because it is assumed that teachers know everything about the language, and that they do not make mistakes. However, as was shown in the example above, the teacher made a mistake. She makes the mistake not because she does not know the answer, but because a word like "cazar" (to hunt) may easily be confused with "casas" (houses).

The maxim was partially flouted. When the teacher corrects herself, it means she realizes that she gave the wrong information, and immediately she repairs it. If she had not corrected it, the maxim would have been completely flouted.

\section{Extract 2:}

T: Sadly, we burn trees, what is the meaning of burn?

S: nacer

(to be burn)

The teacher is talking about the way in which some humans act. In this case, the teacher asks a question in order to make sure that students understand the word burn. She asks the question, and then the student answers incorrectly. It seems that he understood the word to be born.

The maxim of quality is flouted, because the student's answer is incorrect. He does not provide an adequate answer to the teacher's question. As he is the only person who answers the question, the rest of the students may think that the word burn is "nacer" (to be born). As stated by Kocaman (2016), "the same word may have several meanings and a student may interpret the other meaning other than the implied meaning" (p. 1782). Pakbaz, Bigdeli, Moolaey, and Ghaffari (2014) call this situation the semantic barrier (Kocaman, 2016). Escribano (as cited in Kocaman, 2016), states that:

the lack of word knowledge sabotages the production of thought. Poor word knowledge in the target language causes encoding the message in a wrong way. If they even force themselves to think in the target language, this does not make a significant difference. Negative transfer of L1 is again very common issue. False cognates may enforce students. Almost same written words in L1 and L2 may have different meanings. Especially, in the beginning of the process of learning a foreign language, learners frequently come across this kind of problem. (p.1783)

\section{Extract 3:}

T: What is the meaning of this is up to us?
S: es tiempo de
(it is time to)

The teacher wants to know if students know the expression "this is up to us". She asks a question, and one student answers incorrectly. The answer does not have to do with what the teacher is asking.

The maxim is flouted due to the wrong information that student provides. Perhaps, he understood another expression. 
In this case, the answer does not correspond to the teacher's question at all.

As it was shown and explained, the teacher or students, in most of the cases, flouted this maxim because of the wrong information they gave when they tried to answer a question. Although communication continued between both parties, it is an example of how we violate maxims when we communicate. In most cases, we do not realize that we violate maxims. This is because, in my opinion, oral communication is not planned; it happens spontaneously and, at times, unconsciously. We are not totally conscious of how we direct the communication process. That is why Grice (1975) found that when speakers communicate, there are some implicatures in that process. According to his theory of communication, speakers do not realize these implicatures because they prefer to continue with the conversation. However, he argues that misunderstandings and problems with communication occur due to violations of these maxims.

From a linguistic perspective, there are two components to explain why speakers do not pay attention to grammar issues and instead continue with the communication process. These components are the Linguistic Competence and Communicative Competence. The first component, stated by Chomsky (1965), emphasized the differences between linguistic competence, the speaker-hearer's knowledge of his language and performance, and the actual use of language in concrete situations. He points out that linguistic theory is concerned primarily with an ideal speaker-listener, in a completely homogeneous speech-community, who knows its language perfectly and is unaffected by such grammatically irrelevant conditions as memory limitations, distractions, shifts of attention and interests, and errors (random or characteristic) in applying his knowledge of the language in actual performance. (as cited in Paultston, 1974, p.4)

Speakers assume that as native speakers of a language, they do not have linguistic problems, or that these are not relevant in communication. That is why, when we speak, we focus on what the person says instead of how they say it.

According to Dell Hymes (1972), as cited in Naour (n.d.), Chomsky's notion of competence in terms of the ideal speaker-listener in a homogeneous speech community does not provide a place for the competence of language use. Hymes (1972), who was concerned with linguistic theory and the socio-cultural aspect of language, stated that,

what one is inevitably concerned with is "performance" - the actual use of language in a concrete situation; its use moreover by speaker-listeners who are far from "ideal" and whose language behavior cannot be characterized as that of any "homogeneous speech community." (p.12)

\section{Maxim of relation or relevance}

"Relevance of information provided when people answer questions" (Grice, 1975).

\section{Extract 4:}

T: Why people cut trees? What is the reason? What for? 
S: How do you say "leñador"?

(woodcutter)

T: Ok, why? Why? Do you know what is the meaning of why?

This example may apply for two maxims: relation and manner. The violation of the first maxim is evidenced when the information given by the student does not correspond to the question that the teacher asked. Also, when the student asked his question, the teacher did not give any information. Instead, she asked a different question. There is no relation between the three questions. When the teacher asked the first question, the student did not feel it was relevant to answer. Instead, he preferred to ask a different question. Then, the teacher did not find it relevant to answer the student's question. Rather, she preferred to focus on the first question she asked, which was "Why people cut trees?".

On the other hand, if we focus on the maxim of manner, in Grice's words, talking must be brief (avoid unnecessary prolixity) and orderly. This maxim was flouted when the teacher asked students three questions in the same intervention that she did.

Although the three questions are related to each other, it seems that the student does not follow the order of the questions, and he prefers asking a different question. However, the teacher does not follow the student's question, and she asks two different, unrelated questions. First, she asks "why" referring to the first question she asked, and then she asked for the meaning of why.
If we follow Grice's theory about this maxim, the teacher does not follow an organized set of questions. That is why, in my opinion, the student did not follow the question. At the end, he focuses on a different question. Also, it is interesting to see how as teachers, we sometimes ask a question using a Wh- question word, and then we ask the meaning of that Whquestion word. Perhaps, we assume that students know the answer to what we are asking, but when they do not answer, we ask the meaning of the Wh- word. This done, perhaps, to check if the problem is related to the meaning of the Wh- word or the content of the question. In this case, the teacher wanted to know if students understand the Spanish word for why. Kannan (as cited in Kocaman, 2016), points out that

the use of native language is a serious language barrier for learners. EFL learners always translate their sentences from the native language to the target language in their minds. Kannan's study (2009) explained that this method makes the learning slow and to acquire the language, students should have a chance to practice in the target language. Teachers need to provide the environment for students in order that they can practice. (p. 1783)

\section{Extract 5:}

T: What kind of food can we have from trees? S3: Because the animals life in the trees*

*(Life was the word the student used, instead of live)

This maxim is flouted because the student's answer is not relevant to the teacher's question. Although the answer is correct, because certainly some animals 
live in the trees, the answer does not correspond to what the teacher is asking.

It may happen that, sometimes, students do not understand the question, and they only understand some words. Based on the words they understand, they answer the questions asked. In this case, the student understood the word "trees", and as the class is about nature, the planet, animals, etc., the student automatically relates the word with the topic and answers. At times, students do not pay attention to whether they answer correctly. Instead, they really want to participate and communicate somehow, which based on some scholars and teachers, this is the purpose of the language classroom: to communicate.

As mentioned in the introduction, this study does not focus on how teachers and students make mistakes in the English language classroom. Rather, the focus is on what happens in the classroom in relation to communication. Do we pay attention to these issues? How relevant are these situations when we focus on communication? Are these issues, perhaps, the reason why communicating in English inside the classroom is so difficult? How effective is the communicative approach in a monolingual context? How do we communicate in the language classroom? What do we understand by communication? Is it an utterance produced by a student without minding whether it is right or wrong, relevant or not among others?

\section{Maxim of manner}

"The intention is 'to be clear'. Avoid obscurity and ambiguity, and be brief and organized" (Grice, 1975).

\section{Extract 6:}

T: Do you think is the video ok? Or, aren't you understanding? Ok, is it too fast?

Ss: Yeah

The teacher asks three questions. The first question has to do with asking students if they think that the video is good for them. In the second one, she asks students if they are understanding what the video is showing. In the last one, she is asking about the speed of the video. She may be worried because the man in the video talks too fast, and the students may not understand what he says. Finally, all students answer, "yeah".

The maxim of manner is flouted because the students' answer is not clear to which one of the questions it belongs to. In this case, "yeah" is a response to which of the questions, and what does it mean? It could have several interpretations, such as "Yes, the video is ok", "yes, we are not understanding anything", or "yes, it is very fast". It is difficult to recognize which questions is being answered by the students' utterance. The teacher also flouted this maxim when she asks three different questions at the same time. She does not follow the order of asking questions. Although the three questions are related to the video, why does the teacher ask three questions that may require different answers?

This is a very common mistake that we, as teachers, make. Perhaps, the intention is to promote interaction by asking more than one question at a time, but the analysis of this maxim represents a different panorama. The students' answer 
seems to be confusing and ambiguous. Sometimes, it is the case that we ask questions to all of the students assuming that all of them are going to agree on the same answer. It is important to reflect upon how questions are asked and what kind of answers the teacher may obtain in order to avoid obscurity and ambiguity in answers.

\section{Extract 7:}

T: How are we destructing the earth?

$S$ : Because trees and money the importation humans

The student's answer seems to be a response for "Why" instead of "How". His answer is not clear at all; it is not clearly organized. He talks about trees, money, importation and humans, but it is difficult to recognize what he wants to express. Although he selects some words related to the topic, the information given is confusing.

This is commonality in the language classroom. Students try to select some words in order to initiate a communicative act. Although students may select appropriate words, the information is not well organized. Of course, as they are beginners, their English level does not allow them to provide well organized and structured answers. It is understandable that based on their English level, they cannot always produce comprehensible questions and answers. It does not mean that they cannot participate, or that every time they want to communicate, they have to do it correctly. However, many times communication is broken and it becomes incomprehensible because of the violation of this maxim.

To solve this problem, teachers usually ask "what do you want to say?" in order to help students organize their ideas. Sometimes, asking in the mother tongue gives students confidence to talk about what they want to express. According to Atkinson (1987), Auerbach (1993), Cook (2001), Harbord (1992), Johnson and Lee (1987), Kang (2008) and Kern (1989), as cited in Pan Yi-chun and Yi-ching (2010), "the use of L1 may assist students in reducing affective barriers and increasing their confidence in their ability to successfully comprehend the TL" (p.89).

\section{Extract 8:}

T: Why? Why is he sorry? What is the meaning of sorry?

S: Sorry the humans sorry the destruction.

The teacher asks three questions, which means three opportunities to answer. In the first question, she only asks "why". Then, immediately, she restates the question and asks about the reasons why the man in the video is sorry. Then, she asks for the meaning of sorry. The student decides to answer, but his answer is not clear.

The teacher asks two different questions, the second and the third one. These questions are different in meaning. Each one of these requires a different answer. The way she presents the questions is not effective, and the student's answer is vague and ambiguous. It is difficult to know at first which question his answer belongs to. Second, it is unclear what 
he wants to say. This maxim is flouted because the questions are not the same, and also because the student's answer is not comprehensible. In the same way, the maxim of relation is flouted because none of the answers correspond to the questions asked by the teacher. The student does not answer the reason why the man in the video is sorry, or does he answer what the meaning of sorry is.

In the questions the teacher asked, she assumes that students know what sorry means, and that is why she asks about the reasons why the man in the video is sorry. Immediately, she assumes that students may not know what sorry means, and then she asks the meaning of the word.

A crucial point in what follows, however, is that system-dialogue breaks down when users ask questions of the system. A key, therefore, to the successful design of system-directed dialogue is to design the dialogue in such a way that users do not need to ask questions of the system. To do this requires optimizing the dialogue cooperativity of the system. (Bernsen et al., as cited in Davies, 2000, p. 5)

\section{Extract 9:}

T: there is a problem between trees versus money. What is the problem there?

$S:$ que... the money are destructor trees (that)

The teacher presents a possible problem between trees and money. Then, she asks students to talk about what the problem is between these two aspects. Then, a student decides to answer. He starts his talk with a word in Spanish. Although his answer mentions two aspects, it is not clear. Even if the answer were "the money is destructing trees", which is grammatically "correct", the answer seems to be unclear.

As I have discussed before, this tends to occur in classrooms where English language exposure is low. Students hardly try to communicate, and most of the time, they do it using single words, hesitating and switching to Spanish. It does not mean that students have to communicate perfectly, but they rarely pay attention to how they say what they want to say.

\section{Conclusions}

This analysis may contribute to the field of language teaching, in the sense that it may help reflect about how communication usually occurs in classrooms. As teachers realize how communication is carried out in the language classroom, new ideas and strategies may emerge in order to enhance communication in the classroom. This does not mean that communication must be perfect, but it is an opportunity to analyze and think about the concepts each one of us has about communication. Grice (1975) states that communication, seen as a communicative act, needs the cooperation of its participants. It is necessary to determine if we cooperate with students when we communicate, and what is understood by our communication.

As evidenced, communication in a foreign language is not easy to carry out in the language classroom. Teachers use different strategies in order to foster interaction. As the analysis shows, one of those strategies is asking more than once. 
Teachers help students to organize ideas and initiate an utterance. Sometimes, students do not participate because they do not know what to say, or because they do not know how to say it.

The analysis of this reflective paper shows that, in this case, the teacher and students mostly flouted maxims of quality and manner. In my opinion, this happened because English is not their native language. This does not mean that if we focus on mother tongue analysis, these violations will not happen, but there is a higher possibility of it happening in the foreign language. This is especially the case in Colombia where Spanish is used predominantly over English.

Although communication did not achieve its purpose in many cases, the video shows that students try to communicate in the foreign language, even if they do not how to say what they want to say. Using single words is one of the ways students try to communicate in the language classroom. It is not easy to enhance oral communication in a monolingual context like Colombia, especially when English is only seen as a requirement to graduate from schools and universities. Students only receive three or four hours per week, and in most cases, Spanish is more frequently used than English in English class.

\section{Pedagogical implications}

Reflecting about the way in which communication is carried out inside the classroom is a task that we, as language teachers, should do constantly. It is important to know about these maxims in order to direct communication towards a more effective process. Sometimes, we accept what our students say, even if their ideas do not make any sense. That is why, communication is broken in the classroom. Sadly, teachers rarely study the causes for why effective communication does not occur in the foreign language, and instead, they prefer to continue the class by switching to Spanish.

It is important to understand why students in Colombia take English from elementary school to college, but few people speak the language. English teachers use different methods such as grammar translation method, communicative approach, and others, but it seems that none of these methods work effectively. It has been seen in the classroom, and even in the results of the Pruebas Saber Pro, an official exam proposed by the ICFES (Instituto Colombiano para el Fomento de la Educación Superior $)^{4}$ and prepared by the Ministry of Education, that many students struggle with English. Even in some universities, where it is assumed that students have taken English for many years prior to entry, rarely reach level A1 upon entering college. One of the reasons that explains these problems could be the way in which language teachers interact with students. As mentioned by Kocaman (2016):

As to make a good relationship with others, Cüceloğlu (2002) states that the most important thing in communication is the necessity of communicating with

4 Colombian Institute for the Promotion of Higher Education 
ourselves. A good communicator is able to evaluate both his inner world and the behaviors of another person in a realistic way. The person, who is aware of others, understands what kind of inner world their behaviors come from and comprehend their experiences. The one who has a good communication talent immediately sees the clues about the other's posture, intonation and inner world whom one communicates with and tries to evaluate those clues immediately. (p. 1781)

Thus, we, as language teachers, should evaluate and think about how we address these maxims proposed by Grice. What happens when a student does not answer what I ask him? What happens when a student does not understand what I say in the foreign language? Do I assume that they know certain things, and that is why I do not pay too much attention to what they say? Of course, mistakes are part of the English learning process, but what is my role as a languages teacher? Do I reflect about the way students and I communicate? Upon reflection, we can better understand how our communication affects our students and individual contexts.

\section{References}

Communication [Def. 5]. (n.d.). In Merriam Webster Online, Retrieved February 18, 2017, from https://www. merriam-webster.com/dictionary/ communication

Communication [Def. 1]. (n.d.). In Cambridge Online Dictionary, Retrieved
February 18, 2017, https:/ / dictionary. cambridge.org/es/diccionario/ ingles/communication

Davies, B. (1997). An empirical exami-nation of cooperation, effort and risk in taskoriented dialogues. Unpublished PhD thesis. University of Edinburgh.

Davies, B. (2000). Grice's Cooperative Principle: Getting the meaning across. Retrieved from https://es.scribd. com/document/338217455/Daviesabout-Grice-s-cooperative-principlepdf

Du, Y. (2016). The Use of First and Second Language in Chinese University EFL Classrooms. Doi: 10.1007/978-981-101911-1

Escavy, R. (1998). El principio de cooperación y las violaciones antagónicas. Universidad de Murcia. (pp. 31-40). Retrieved from https://www.uv.es/ perla/3[03].Escavy.pdf

Fajardo, J. (2013). "What makes a teacher": Identity and classroom talk. Cuadernos de lingüística hispánica, 22, 127-146.

Grice, H. (1975). Logic and conversation. Harvard University: Harvard University Press.

Grice, H. P. (1975). Logic and Conversation. In P. Cole, \& J. L. Morgan. (Eds.), Syntax and Semantics, Vol. 3, Speech Acts (pp. 41-58). New York: Academic Press.

Kocaman, O. (2016). Communication barriers that junior and senior ELT students experience in the process of learning a foreign language. Abant 
İzzet Baysal Üniversitesi Eğitim Fakültesi Dergisi, 16 (4), 1779-1794.

Nouar. Y, (n.d.). Linguistic competence, communicative competence, pragmatic competence and their implications for foreign language teaching and testing. Retrieved from http:/ / fac. umc.edu.dz/fll/images/expressions/ Yasmina-NOUAR.pdf

Pakbaz, M., Bigdeli,H., Moolaey, F. and Ghaffari, A. (2014). Organizational communication and barriers to effective communication in organizations. International Journal of Management and Humanity Sciences, 3(10), 31743180 .

Pan, Yi-chun., and Pan, Yi-ching. (2010). The use of L1 in the foreign language classroom

Paultston, C. (1974). Linguistic and communicative competence. TESOL QUARTERLY, 8, 347-362.

Shardimgaliev, M. (2016). Grice's theory of communication and interpretation of law. Retrieved from http:/ / punzel. org/Book2016/Shardimagliev-Final. pdf

Wharton, T. (2003a). Interjections, language and the 'showing' /'saying' continuum. Retrieved from http://www. phon.ucl.ac.uk/publications/WPL/ 00papers/wharton.pdf

Wharton, T. (2003b). Paul Grice, saying and meaning. Retrieved from http:// ftp.phon.ucl.ac.uk/home/PUB / WPL/02pa pers/wharton.pdf 